\title{
The Distribution of 2-Keto-3-deoxy-octonic Acid in Bacterial Walls
}

\author{
By D. C. ELLWOOD \\ Microbiological Research Establishment, Porton Down, Salisbury, Wiltshire
}

(Accepted for publication I8 November 1969)

SUMMARY

\begin{abstract}
A survey of the walls of over 80 bacterial species has been carried out using chromatographic and colorimetric techniques to demonstrate the presence of 2-keto-3-deoxy-octonic acid (KDO) and or sialic acid. In most Gram-negative bacteria KDO but not sialic acid was found in the wall, whereas the walls of Gram-positive bacteria contained neither compound.
\end{abstract}

\section{INTRODUCTION}

2-Keto-3-deoxy-D-manno-octonic acid (KDO) was first recognized as a glycosidic component of the lipopolysaccharide (LPS) of Escherichia coli or I B 4 (Heath \& Ghalambor, 1963; Ghalambor, Levine \& Heath, I966), but subsequently it has been found in the lipopolysaccharides of all the members so far examined of the Enterobacteriaceae (Lüderitz, Staub \& Westphal, I966; Williams \& Perry, 1969). Furthermore, some strains of Pasteurella and Brucella contain KDO in the lipopolysaccharide fraction of their cell wall (Ellwood, 1968).

Two other 2-keto-3-deoxy-sugar acids have been reported as structural components of bacteria. 2-Keto-3-deoxy-galactonic acid occurs in an extracellular polysaccharide of Azotobacter vinelandii, and sialic acid ( $N$-acetylneuraminic acid), an $N$-acetyl amino substituted 2-keto-3-deoxy-sugar acid containing 9 carbon atoms, occurs in a polymeric form in several bacteria (Barry \& Goebel, I957; De Witt \& Rowe, I959). All 2-keto3-deoxy-sugar acids give a positive reaction with thiobarbituric acid after acid periodate oxidation, and on the basis of this non-specific test it was initially thought that sialic acid was widely distributed in Gram-negative bacteria (Aaronson \& Lessie, I960; Irani \& Ganapathi, I962). Later, on the basis of a similar test, it was suggested that KDO was equally widely distributed (Vincent \& Cameron, 1967).

In order to clarify this apparent contradiction a survey has been carried out using both colorimetric and chromatographic analysis for the presence of 2-keto-3-deoxysugar acids in the cell walls of a wide selection of bacteria. Since lipopolysaccharides are components of the envelopes of Gram-negative bacteria, KDO is expected to occur in the wall preparations of the Gram-negative bacteria only, nevertheless, both Grampositive and Gram-negative organisms were examined. A preliminary report has been published (Ellwood, I966). 


\section{METHODS}

Organisms. The bacterial species examined are shown in Table 2. They were obtained from the following collections: American Type Culture Collection, Rockville, Md., U.S.A. (ATCC); Microbiological Research Establishment, Salisbury (MRE); National Collection of Industrial Bacteria, Torry Research Station, Aberdeen (NCIB); National Collection of Marine Bacteria, Torry Research Station, Aberdeen (NCMB); National Collection of Type Cultures, Central Public Health Laboratory, London (NCTC); Rothamsted Experimental Station, Harpenden (RES); National Collection of Dairying Organisms, National Institute for Research in Dairying, Reading (NCDO); National Collection of Plant Pathogenic Bacteria, Harpenden, Herts. (NCPPB).

Culture conditions. Bacteria were grown on the surface of a plate count agar (Oxoid) at temperatures facilitating maximum rate of growth. Organisms were harvested by scraping the bacteria from the agar surface with a spatula, washed with saline and disrupted as described below. Three plates $(9 \mathrm{~cm}$. diameter) yielded 200 to $300 \mathrm{mg}$. of bacteria.

Preparation of bacterial walls. Bacteria (c. $300 \mathrm{mg}$. equivalent dry wt in $30 \mathrm{ml}$. water) were shaken in a vertical shaker (stroke $10 \mathrm{~cm}$.) at 450 strokes $/ \mathrm{min}$. in volumes of Io $\mathrm{ml}$. with Ballotini beads (Io ml. no. I 6 grade), for I hr. The Ballotini beads were then removed by filtration through a no. 2 glass sinter and the walls were separated by centrifugation $(17,000 \mathrm{~g} ; \mathrm{I} \mathrm{hr})$, washed 3 times in saline $(\mathrm{I} \%, \mathrm{w} / \mathrm{v})$ and 3 times in water, lyophilized, and weighed. Yield 30 to $60 \mathrm{mg}$. initial dry wt of bacteria. The optimum conditions for the release of KDO from wall preparations were established using wall samples of Escherichia coli MRE600, and Klebsiella (Aerobacter) aerogenes

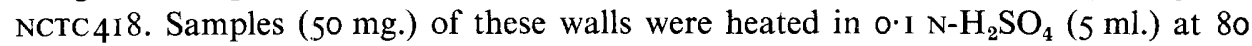
and $100^{\circ}$. The release of KDO was followed by analysing samples by the method described below.

Isolation of the 2-keto-3-deoxy-sugar acids. The samples of bacterial walls (50 mg.)

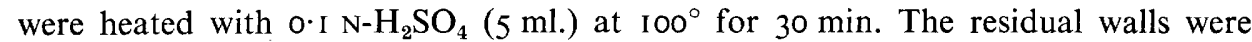
sedimented by centrifugation ( $17,000 \mathrm{~g} ; \mathrm{I} 5 \mathrm{~min}$.). The supernatant fluid was neutralized with a saturated solution of $\mathrm{Ba}(\mathrm{OH})_{2}$, centrifuged to remove $\mathrm{BaSO}_{4}$, and passed through a column $\left(0.5 \mathrm{~cm}\right.$. long and $\mathrm{I} \cdot 0 \mathrm{~cm}$. diam.) of Dowex $\mathrm{I}\left(\mathrm{HCO}_{3}{ }^{-}\right.$form $)$. The column was then washed with water $(5.0 \mathrm{ml}$.) and the eluate and washings discarded. The column was eluted with $0.5 \mathrm{~N}$-ammonium carbonate $(5 \mathrm{ml}$.), the eluate treated with an excess of Dowex $50\left(\mathrm{H}^{+}\right.$form $)$and the resin removed by filtration. The filtrate was lyophilized and then dissolved in water ( $0.1 \mathrm{ml}$.) for chromatographic analysis.

Determination of 2-keto-3-deoxy-sugar acids. This was a modification of the methods of Weissbach \& Hurwitz (1959) and Aminoff (196r). Samples (0.2 ml.) of the acid hydrolysates of the wall samples were diluted with water (o. I ml.). Periodic acid $\left(0.025 \mathrm{M}\right.$ in $0.125 \mathrm{~N}^{-} \mathrm{H}_{2} \mathrm{SO}_{4} ; 0.25 \mathrm{ml}$.) was added and incubated at about $20^{\circ}$ for $20 \mathrm{~min}$. Sodium arsenite $(2 \%, \mathrm{w} / \mathrm{v}$ in $0.5 \mathrm{~N}-\mathrm{HCl} ; 0.5 \mathrm{ml}$.) was next added, shaken, and allowed to stand until the yellow colour was discharged ( 2 to $3 \mathrm{~min}$.). Thiobarbituric acid $(0.3 \%$, $\mathrm{w} / \mathrm{v}, \mathrm{pH} 2.0 ; 2.0 \mathrm{ml}$.) was then added and, after shaking, the solution heated to $100^{\circ}$ for Io min. The pink solution was cooled to $4^{\circ}$ (when it became cloudy) and shaken with $5.0 \mathrm{ml}$. of conc. $\mathrm{HCl}+n$-butanol $(5+95, \mathrm{v} / \mathrm{v})$. After centrifugation the extinction of the coloured upper layer was measured in a spectrophotometer at $550 \mathrm{~m} \mu$. Under these conditions an opticall extinction of 0.430 was obtained from $0.025 \mu$ mole of KDO. 
Paper chromatography. This was done on acid-washed Whatman no. I paper with the following solvent systems: (A) butan-2-ol+acetic acid + water $(8+I+I, v / v)$, and (B) butan-I-ol + pyridine $+0 \cdot \mathrm{I} \mathrm{N}-\mathrm{HCl}(5+3+2, \mathrm{v} / \mathrm{v})$. Paper chromatograms were dried and developed by the technique of Anderson (1966).

Preparation of 2-keto-3-deoxy-sugar acids (chromatographic standards). These were prepared by aldol condensation between the appropriate aldose and oxaloacetic acid in alkaline solutions, as described by Ghalambor et al. (I966). Glyceraldehyde gave a mixture of 2-keto-3-deoxy-gluconic acid (KDG) and 2-keto-3-deoxy-galactonic acid. These acids ran as one component in both solvents and were used as a chromatographic standard for KDG. Erythrose also gave a mixture of two 2-keto-3-deoxyheptonic acids. The major component was used as a chromatographic standard for 2-keto-3-deoxy-heptonic acid $(\mathrm{KDH})$. Authentic KDO was kindly supplied (as the penta-acetyl methyl ester) by Dr E. C. Heath; $N$-acetylneuraminic acid was purchased from Koch-Light Laboratories (Colnbrook), Bucks., England.

\section{RESULTS}

The determination of KDO depends upon oxidation with periodate under acid conditions to give $\beta$-formyl pyruvate, which is then reacted with thiobarbituric acid to form a chromagen with an absorption maximum at $550 \mathrm{~m} \mu$. The assay of Weissbach \& Hurwitz (1959) is based upon these reactions but has been modified by extracting the

Table 1. Separation of various 2-keto-3-deoxy-sugar acids by paper chromatography

\begin{tabular}{ccccc} 
& \multicolumn{4}{c}{} \\
\cline { 2 - 4 } Solvent & KDG & KDH & KDO & $\begin{array}{c}N \text {-acetyl- } \\
\text { neuraminic acid }\end{array}$ \\
A & $\mathrm{I} \cdot 78$ & $\mathrm{I} \cdot 4 \mathrm{I}$ & $\mathrm{I} \cdot 00$ & 0.85 \\
B & $\mathrm{I} \cdot 93$ & $1 \cdot 37$ & $\mathrm{I} \cdot 00$ & 0.84
\end{tabular}

Solvent A: butan-2-ol+acetic acid + water $(8+\mathrm{I}+\mathrm{I}, \mathrm{v} / \mathrm{v})$.

Solvent B: butan-I-ol-pyridine $+0 \cdot \mathrm{IN}-\mathrm{HCl}(5+3+2, \mathrm{v} / \mathrm{v})$.

chromagen into acid butanol (cf. the assay method for sialic acid, Aminoff, 1961). This extraction step prevents precipitation which otherwise tends to occur at room temperature. The results obtained in this assay are largely specific for $\mathrm{KDO}$ : equimolar solutions of $N$-acetylneuraminic acid give less than $\frac{1}{20}-$ the colour reaction. The $R_{F}$ values of the series of 2-keto-3-deoxy-sugar acids are shown in Table $\mathrm{I}$ and it is apparent that the acids may be differentiated by paper chromatography in these solvents.

Fig. I shows the rate of release of 2-keto-3-deoxy-sugar acids from walls of Escherichia coli and Klebsiella aerogenes by acid hydrolysis at 80 and $100^{\circ}$. The maximum release of these acids from both wall samples was obtained after heating for $30 \mathrm{~min}$. at $100^{\circ}$ and these conditions were used for all other wall samples investigated. Paper chromatography of hydrolysates prepared by the standard procedure showed the presence of KDO in nearly all the wall samples of Gram-negative bacteria examined. $N$-acetylneuraminic acid was found in only a few samples. In wall preparations of Gram-positive bacteria no trace of either KDO or $N$-acetylneuraminic acid was found. The results are summarized in Table 2. 
Table 2. The 2-keto-3-deoxy-sugar acids found in bacterial walls

Species

Athiorhodaceae

Rhodopseudomonas

palustris

R. spheroides

Pseudomonadaceae

Pseudomonas aeruginosa

$P$. angulata

P. chlororaphis

$P$. fluorescens

P. iodinum

P. primulae

$P$. syncyanae

Xanthomonas campestris

$X$. hyacinthi

$X$. juglandis

Acetobacter aceti

Aeromonas hydrophila

A. liquefaciens

Protoaminobacter alboflavus

Mycoplana bullata

Spirillaceae

Vibrio cuneatus

V. foetus

$V$. percolans

Rhizobiaceae

Rhizobium leguminosarum

Agrobacterium tumefaciens

Chromobacterium violaceum

Achromobacteraceae

Alcaligenes faecalis

A. metaligenes

Achromobacter lacticum

Flavobacterium acidificum

F. aurantiacum

F. sauveolens

Agarbacterium alginicum

Enterobacteriaceae

Escherichia coli

\section{E. freundii}

Klebsiella aerogenes

Paracolobactrum aerogenoids

Klebsiella aerogenes

Erwinia amylovora

E. carnegieana

Serratia keilensis

$S$. marcescens

Proteus vulgaris
Strain number

KDO*

$N$-acetylneuraminic acid*

$\mathrm{KDO}$ in the cell wall

$(\%)$

Gram-negative bacteria$$
\begin{aligned}
& \text { NCIB } 8252 \\
& \text { NCIB } 8253 \\
& \text { 1.s. } \\
& \text { NCPPB } 263 \\
& \text { NCIB } 9402 \\
& \text { KB I } \\
& \text { NCIB } 8248 \\
& \text { NCDO } 613 \\
& \text { NCPPB I } 33 \\
& \text { NCDO } 759 \\
& \text { NCPPB } 528 \\
& \text { NCPPB } 599 \\
& \text { NCPPB } 362 \\
& \text { XJ IO7 } \\
& \text { NCIB } 8554 \\
& \text { NCMB } 72 \\
& \text { NCMB } 87 \\
& \text { NCIB } 8167 \\
& \text { ATCC } 4278 \\
& \text { NCIB } 8194 \\
& \text { ED } 148 \\
& \text { NCIB } 8193
\end{aligned}
$$

RES 317

NCPPB 397

NCTC 7150

NCTC 9373

NCIB 8 I 56

$\mathrm{NCIB} 902 \mathrm{I}$

NCIB 8208

NCMB 683

NCIB 8204

$\mathrm{NCIB} 8992$

NCMB 886

MRE I 62

NCTC 8I 64

MRE 600

NCTC 8165

NCTC 8167

NCTC 8105

NCTC 418

NCPPB 595

NCPPB 671

NCTC 46I9

NCTC 1377

NCIB 8064
$+$

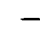

O. I

0.1

0.6

0.5

0.5

0.4

0.5

0.05

$<0.01$

0.1

0.7

0.1

O.I

0.1

0.2

0.05

0.05

$<0.0 I$

$<0.0$ I

0.2

0.7

0.4

0.6

0.3

0.2

0.2

0.2

0.02

0.2

0.3

$<0.01$

$<0.01$

0.02

$<0.01$

0.05

0.4

0.7

0.7

0.5

0.5

0.6

0.5

0.4

0.5

0.2

0.5

0.4 
Table 2 (cont.)

Species

P. mirabilis

Salmonella typhimurium

Shigella shigae

S. flexneri

Brucellaceae

Brucella abortus

B. melitensis

B. suis

Pasteurella pestis

P. pseudotuberculosis

Yersinia enterocolitica

P. multocida

P. tularensis

$P$. septica

Neisseriaceae

Neisseria catarrhalis

\section{Micrococcaceae}

Micrococcus lysodeikticus

Staphylococcus aureus

S. epidermidis

S. lactis

Propionibacterium shermanii

Lactobacillaceae

Lactobacillus plantarum

Brevibacteriaceae

Kurthia zopfii

Corynebacteriaceae

Corynebacterium viscosum

C. xerosis

Arthrobacter globiformis

Bacillaceae

Bacillus anthracis

B. brevis

B. megaterium

B. subtilis

Mycobacteriaceae

Mycobacterium smegmatus

Actinomycetaceae

Actinomycetes bovis
Strain number

KDO*

$N$-acetylneuraminic acid*

$\mathrm{KDO}$ in the cell wall

$(\%)$

Gram-negative bacteria

\author{
PR-27 \\ MRE LT/2 \\ NCTC 4837 \\ NCTC 8192
}

$+$

$0 \cdot 3$

0.6

$<0.01$

0.3

544

$45 / 0$

$45 / 20$

6015

PS III KG 25 MRE 43

TS MRE 100

EV 76 MRE 103

MRE 32 IV

l.s.

l.s.

MRE I 25

l.s.

-
-
-

$0 \cdot 3$

0.2

0.1

0.3

0.4

0.5

0.4

0.4

0.3

0.1

$<0.01$

0.05

NCTC 8554

0.05

Gram-positive bacteria

\begin{tabular}{|c|c|c|c|}
\hline MRE 3IO & - & - & $<0.01$ \\
\hline NCTC $675 \mathrm{I}$ & - & - & $<0.01$ \\
\hline l.s. & - & - & $<0.01$ \\
\hline NCTC 7944 & - & - & $<0.01$ \\
\hline l.s. & - & - & \\
\hline 1.s. & - & - & $<0.01$ \\
\hline NCTC 404 & - & - & $<0.01$ \\
\hline NCTC 2416 & - & - & $<0.01$ \\
\hline NCTC 9755 & - & - & $<0.01$ \\
\hline NCIB 8907 & + & - & 0.02 \\
\hline NCTC 8234 & - & - & $<0.01$ \\
\hline NCTC 7577 & - & - & $<0.01$ \\
\hline NCTC 2607 & - & - & $<0.01$ \\
\hline ATCC 9372 & - & - & $<0.01$ \\
\hline NCTC 8 I 59 & - & - & $<0.01$ \\
\hline NCTC 9430 & - & - & I \\
\hline
\end{tabular}

* KDO and $N$-acetylneuraminic acid were characterized and detected by paper chromatograph in solvents $\mathrm{A}$ and $\mathrm{B}$ while $\mathrm{KDO}$ was estimated by a modification of the method of Weissbach \& Hurwitz (1959). Laboratory strains are identified as l.s. Strains whose designations are unspecified in the text were gifts from Dr H. E. Wade and Dr J. Keppie of this establishment. 


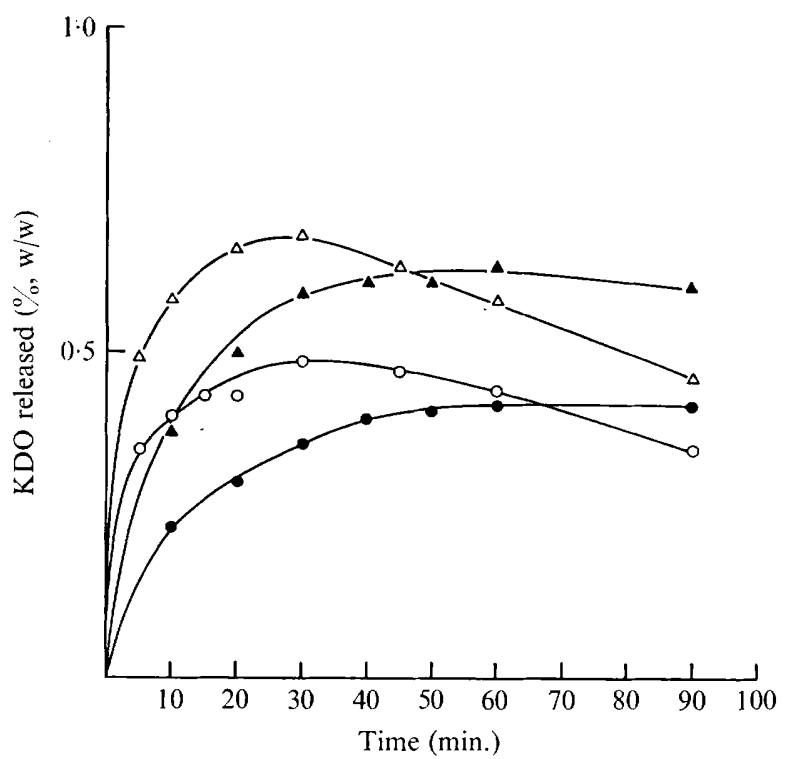

Fig. I. Release of $\mathrm{KDO}$ from walls of Escherichia coli MRE 600 (50 mg.), at $100^{\circ}(\triangle)$ and $80^{\circ}(\Delta)$, and from Klebsiella aerogenes NCTC $418(50 \mathrm{mg}$.$) , at 100^{\circ}(O)$ and at $80^{\circ}(\bullet)$, by heating samples with $0.1 \mathrm{~N}-\mathrm{H}_{2} \mathrm{SO}_{4}(5 \mathrm{ml}$.). KDO was estimated by a modification of the method of Weissbach \& Hurwitz (1959).

\section{DISCUSSION}

Sialic acid occurs either as a polyneuraminic acid (called colominic acid) in several bacterial species or as part of other heteropolysaccharides, such as the K antigen, in other bacterial species (for review see Lüderitz, Jann \& Wheat, I968). A sensitive test for sialic acid is based on the formation of $\beta$-formyl pyruvic acid upon periodate oxidation and the subsequent formation of a chromagen formed on heating the $\beta$-formyl pyruvate with thiobarbituric acid. This procedure provides the basis of quantitative estimation for sialic acid (Warren, 1969; Aminoff, 196I). The periodate oxidation is carried out in 9 M-phosphoric acid in the Warren procedure and Aminoff used $37^{\circ}$ for the oxidation. The high acid concentration or increased temperature is necessary to get a full release of $\beta$-formyl pyruvate. However, KDO will also yield $\beta$-formyl pyruvate on periodate oxidation and thus give a chromagen with thiobarbituric acid identical to that given by sialic acid.

The Warren procedure was used by Aaronson \& Lessie (1960) and Irani \& Ganapathi (I962), who considered the test to be sufficiently specific to demonstrate the wide distribution of sialic acid in bacteria. Vincent \& Cameron (1967), using the assay system of Weissbach \& Hurwitz (1959) in which periodate oxidation is carried out at room temperature, showed that KDO occurred in a similar range of bacteria to those thought to contain sialic acid by Aaronson \& Lessie (I960). Our results using room temperature for the periodate oxidation confirm in general the presence of KDO and absence of $\mathrm{N}$-acetylneuraminic acid. Recently Hackenthal (I969) showed by ion exchange and paper chromatography that the group-specific polysaccharide of type $\mathrm{C}$ meningococci contained both KDO and sialic acid. 
A further complication in comparing the present work with that of Aaronson \& Lessie (1960) and of Vincent \& Cameron (1967) is that they measured material reactive to thiobarbituric acid in hydrolysates of whole bacteria. These preparations would also contain 2-keto-3-deoxy-sugar acids involved in the metabolic pathways of bacteria. We have used wall preparations because this is the location of LPS and capsular fractions of the organisms. The walls were hydrolysed with acid under conditions known to produce maximum yields of thiobarbituric-acid-reactive material in Escherichia coli and Klebsiella aerogenes and there was no evidence for the presence of 2-keto-3-deoxy-sugar acids with less than 8-carbon atoms.

Nearly all wall samples of Gram-negative bacteria contained KDO. The wide variation in amounts of KDO found may reflect differences in the composition of the walls of different bacteria. However, it is known that the KDO content of the wall of Klebsiella aerogenes depends on the way the organisms are grown. The faster they are grown under $\mathrm{Mg}_{-}{ }^{2+}$ limitation the more $\mathrm{KDO}$ is found in the wall, whereas under carbon-limiting conditions the KDO content of the walls falls with increasing growth rate (Ellwood \& Tempest, I967).

Sialic acid was found with KDO in only three organisms, Achromobacter lacticum NCIB 8208, Escherichia coli MRE 162 and E. freundii NCTC8165, but sialic acid was never found without KDO. Several Gram-negative bacteria appear to have no KDO in their wall, indicating that the LPS may be different in its structure. Kasai (I966) has shown that the LPS of Bordetella species do not contain KDO. None of the wall samples or Gram-positive bacteria examined contained either KDO or sialic acid except for Arthrobacter globiformis NCIB 8907, which contained a small amount of KDO. This organism is not unequivocally Gram-positive.

These results indicate that in contrast to the work of Aaronson \& Lessie (1960) and Irani \& Ganapathi (1962), and in agreement with the work of Vincent \& Cameron (1967), KDO is present in most Gram-negative bacteria. The latter authors also found thiobarbituric-acid-reactive material in Gram-positive bacteria. However, KDG and $\mathrm{KDH}$ occur as normal metabolites in bacteria and would give a thiobarbituric acid reaction in hydrolysates of whole organisms.

Thanks are due to Mr G. R. G. Moody for expert technical assistance.

\section{REFERENCES}

Aaronson, S. \& Lessie, T. (1960). Nonulosaminic acid (sialic acid) in protists. Nature, London 186, 7 I9. Aminoff, D. (196r). Methods for the quantitative estimation of $N$-acetylneuraminic acid and their application to hydrolysates of sialomucoids. Biochemical Journal 81, 384 .

ANDERSON, P. J. (1966). A sensitive reagent for detecting 2-deoxy sugars and 3-deoxy polyols. Journal of Chromatography 2I, I63.

Barry, G. T. \& Goebel, W. F. (1957). Colominic acid, a substance of bacterial origin related to sialic acid. Nature, London $\mathbf{1 7 9}, 206$.

DE WITT, C. W. \& Rowe, J. A. (I959). $N$-O-diacetyl neuraminic acid and $N$-acetyl-neuraminic acid in Escherichia coli. Nature, London $\mathbf{1 8 4}, 38 \mathrm{I}$.

Ellwood, D. C. (1966). The distribution of 3-deoxy-2-oxo-sugar acids in the cell walls of Gramnegative bacteria. Biochemical Journal $99,55 \mathrm{P}$.

Ellwood, D. C. (I968). The 3-deoxy-D-manno-octulosonic acid found in the lipopolysaccharide of Pasteurella species. Biochemical Journal 106, 47. 
Ellwood, D. C. \& Tempest, D. W. (1967). Influence of growth condition on the cell-wall content and composition of Aerobacter aerogenes. Biochemical Journal 105, 9 P.

Ghalambor, M. A., Levine, E. M. \& Heath, E. C. (I966). The biosynthesis of cell wall lipopolysaccharide in Escherichia coli. III. The isolation and characterization of 3-deoxy octulosonic acid. Journal of Biological Chemistry 241, 3207.

HaCkenthal, E. (1969). Distribution of keto-deoxyoctonic acid and sialic acid in N. meningitidis. Journal of Immunology 102, 1099.

Heath, E. C. \& GHalambor, M. A. (I963). 2-Keto-3-deoxy octonate, a constituent of cell wall lipopolysaccharide preparations obtained from Escherichia coli. Biochemical and BiophysicalResearch Communications 10, 340.

IRANI, R. J. \& GANAPATHI, K. (I962). Occurrence of sialic acid in some Gram-positive and Gramnegative pathogenic bacteria. Nature, London 195, 1227.

KasaI, N. (1966). Chemical studies on the lipid component of endotoxin, with special emphasis on its relation to biological activities. Annals of the New York Academy of Sciences 133, 486.

LÜDERITZ, O., JANN, K. \& WhEAT, R. (1968). Somatic and capsular antigens of Gram-negative bacteria in Comprehensive Biochemistry. Ed. by M. Florkin and H. H. Stotz. Extracellular and Supporting Structures, vol. 26, part A, p. 105.

Lüderitz, O., Staub, A. M. \& WestPhal, O. (I966). Immunochemistry of O and R antigens of Salmonella and related Enterobacteriaceae. Bacteriological Reviews 30, 192.

VINCENT, W. F. \& CAMERON, J. A. (1967). Thiobarbituric-reacting materials in micro-organisms. Journal of Bacteriology $93, \mathrm{I} 56$.

WARREN, L. (I959). The thiobarbituric acid assay of sialic acids. Journal of Biological Chemistry 234, I97I.

Weissbach, A. \& HuRwitz, J. (1959). The formation of 2-keto-3-deoxyheptonic acid in extracts of Escherichia coli. Journal of Biological Chemistry 234, 705.

Williams, D. T. \& PerRy, M. B. (1969). The structure synthesis and occurrence of 3-deoxy-D-manno octulosonic acid. Canadian Journal of Biochemistry 47, $69 \mathrm{I}$. 